International Review of Research in Open and Distributed Learning Volume 22, Number 1

February - 2021

\title{
Preparing Educators to Teach in a Digital Age
}

Mohsen Keshavarz ${ }^{1}$ and Andrea Ghoneim ${ }^{2}$

${ }^{1}$ Department of Medical Sciences Education Development, Torbat Heydariyeh University of Medical Sciences, Torbat

Heydariyeh, Iran, ${ }^{2 D i g i t a l}$ Teaching Services, Vienna University of Economics and Business, Wirtschafts Universität Wien

\begin{abstract}
This article describes the practical implementation of parts of Teaching in a Digital Age: Guidelines for Designing Teaching and Learning by A.W. Bates (2015) in a course for educators in Austria and the development of medical education for universities in Iran. With the publication of the second edition of Teaching in a Digital Age in 2019, the authors show the impact of the book in training educators and developers of educational content. This note from the field emphasizes the benefits of making informed decisions about educational technologies using Bates' (2015) SECTIONS model and of learning about massive open online courses (MOOCs) and how to work with them using his book.
\end{abstract}

Keywords: educational technology, massive open online courses, MOOCs, open educational resources, OER, media-supported learning, digital teaching skills 


\section{Introduction}

Today, one of the main features of learners in the digital age is to have the skills needed to teach and learn in the new digital environments. Teachers need to be fluent in new technology methods so that they can use new teaching methods in the digital world and make the learning and classroom environment more effective. In line with the mentioned goals, this article is to provide new educational experiences to apply the concepts of new educational technologies in two international environments. To achieve this goal and use a guiding principle, the book Teaching in the Digital Age: Guidelines for Designing Teaching and Learning, a well-known book in the international community in the field of educational technology, was selected by the authors. The main purpose of this article is to present and reflect on the applications of the book Teaching in a Digital Age in two educational settings in Iran and Austria and the main focus is on the application of the SECTIONS model and the concept of MOOCs.

\section{Teaching in a Digital Age}

Teaching in a Digital Age: Guidelines for Designing Teaching and Learning (Bates, 2015) introduces the principles of effective teaching in a digital age and provides instructors with a framework for teaching and learning using technology. The book also offers guidelines for best practices when redesigning teaching to incorporate the use of technology. It offers teachers and instructors the knowledge and skills they need in a digital age. The second edition of Teaching in a Digital Age was published in October 2019 (Bates, 2019a). The first edition of the book has been translated into Chinese, French, Japanese, Portuguese, Spanish, Turkish, and Vietnamese. Parts of the book have also been translated into Farsi. Both editions of the book are available online as an open-access resource (with links to translations of the first edition) through a Canadian organization (BCcampus), under a Creative Commons Attribution-NonCommercial 4.0 International License.

In Chapter 1 of the first edition, Bates (2015) discusses the factors that affect teaching and learning in the world today, including changes in the global economy, the growth of a knowledge society, and the changing nature of jobs. He identifies the skills educators need in the digital age and asserts that faculty must adapt their teaching to the learning styles of the very diverse, new generation of students. Chapter 2 presents epistemological theories on learning, including behaviorism, cognitivism, constructivism, and connectivism. Chapter 3 focuses on the settings and environments of campus-based learning, and Chapter 4 discusses online teaching methods and the limitations of classroom design models for online learning.

Chapter 5 focuses on the concept of massive open online courses (MOOCs). In this chapter, Bates explains the concept of MOOCs, their features and components. The author distinguishes between two types of MOOCs, xMOOC and cMOOC. xMOOC refers to an extended Massive Open Online Course, which has specific and organized assignments, formal evaluation, and a certificate. Future Learn, Canvas, Udacity, Coursera, and edX are among the most well-known xMOOCs in the world (Aldahmani, Al-shami, Adil, \& Sidek, 2020). The "c" in cMOOC refers to connectivist, which represents the nature of cMOOC and involves groups of people learning together rather than learning being facilitated primarily by the instructor. Learners choose what content or skills they want to learn and is personal so there are no formal training plans. In cMOOCs, there is a lot of emphasis on networks, especially the active participation of participants with content (Bates,2019). 
Generally, xMOOC use platforms that are similar to Learning Content Management Systems (LCMS), while cMOOCs, which are based on social learning, use social media platforms and networks (Anderson, 2008). Overall, the main difference between the cMOOC and xMOOC is the educational philosophy that guides them.

He compares the two and describes their strengths and weaknesses. Finally, he describes the political, cultural, and economic impact of MOOCs on university activities. Chapters 6-13 are devoted to the concept of educational technologies and media. Educational media and their characteristics are described, including text, audio, video, and computing, as well as social media, gamification, virtual reality, augmented reality, and artificial intelligence. Bates emphasizes that building a comprehensive and effective learning environment is an important condition for implementing teaching and learning in the digital age.

In Chapter 8, Bates presents the SECTIONS model, a framework for making effective decisions about the choice and use of technology and media in teaching and learning. The SECTIONS model provides a set of criteria that can help an instructor/teacher make decisions about which media or technologies to use.

The SECTIONS model is based on:

- Students

- Ease of use

- Cost

- Teaching functions, including pedagogical affordances of media

- Interaction

- Organizational issues

- Networking

- Security and privacy

In the new model of SECTIONS "S" from "Speed" has changed to "Security and privacy."

Chapters 9 and 10 present a continuum of technology-based learning, from face-to-face to fully online programs. According to Bates, teachers must decide where a particular course or program should be located on the continuum. Chapter 11 describes open educational resources (OER), their principles, sources, and uses and discusses the advantages and limitations of open textbooks, open research, and open data. Chapter 12 defines the quality of teaching in the digital age and proposes a nine-step plan for teaching effectively in an online environment. The final chapter is devoted to the importance of developing and training teachers and instructors for technology-based teaching and learning. The chapter provides a model for promoting knowledge among educators, explains the concept of team teaching, and introduces an institutional strategy for teaching in the digital age. 
The second edition of Teaching in a Digital Age (Bates, 2019a) includes the latest emerging educational technologies. In this edition, the first chapters continue to focus on theory and outline the principles and guidelines for teaching and learning in the digital age. From Chapter 6 onward, the book moves from theory into practice and identifies essential processes for teaching in the digital age. Both editions of the book are intended for teachers and educators, but the book can also help students develop the knowledge and skills required for learning in the digital age. Furthermore, the book is relevant for instructional designers, curriculum planners, instructors, K-12 teachers, teacher candidates, and educational administrators engaged in redesigning classrooms. Teaching in a Digital Age provides solid guidance for decision making regarding whether courses should be face-to-face, blended, or fully online (Bates, 2015, 2019a).

Both editions of the book offer clear images, diagrams, videos, and photos, as well as links to podcasts. Each section in the chapters begins with a scenario to help readers draw a concept map of the subject matter. Suggested activities add to the discussion, and references and suggestions for further reading appear at the end of each section. "Key Takeaways" at the end of each chapter summarize its practical implications for teaching and instructional design (Bates, 2015, 2019a).

The first edition of Teaching in a Digital Age was greeted with great interest by educators who mostly played the role of educational designer, and several reviews have been published. Serpil Kocdar (2017) from Anadolu University, for example, emphasizes the interactive nature of the book: "It combines theoretical and conceptual knowledge with practical information by presenting scenarios from real-life experiences, reflective questions in the activities, podcasts, videos, and the author's observations. I felt a continuous interaction with the author while reading the book." The book was added to the Multimedia Educational Resource for Learning and Online Teaching (MERLOT) resources in 2016, and a peer review was published on the MERLOT website in 2018 (Teacher Education, 2018). Other reviews of the book have focused on its usefulness for teaching and continuing education for individuals involved in adapting teaching and learning for technology-rich scenarios (Duzenli, 2018; Mulyono, 2017). The translation of the first edition of Teaching in a Digital Age into several languages further demonstrates the respect and attention this book has received.

\section{Using the SECTIONS Model in an e-Education Program at Danube University Krems}

Danube University Krems, Austria, is an institute for continuing education. Until 2019, it mainly offered master's-level programs, with a focus on students who have work experience. The programs are, for the most part, designed so that students can pursue their studies while continuing to work. Thus, most courses are offered through blended learning. An e-education program has been offered at Danube University since 2007. It is a master's-level program and consists of 90 European Credit Transfer and Accumulation System (ECTS). The program is modular in design, and most modules grant 3 ECTS. The core modules in the first two terms are Educational Technology (Bildungstechnologie) and Didactic Design. Each of these modules grants 6 ECTS (Himpsl, 2010). The working language is German. All modules are delivered through blended learning, with short face-to-face periods.

In the educational technology module, students become acquainted with learning theories (based on Baumgartner, 2004) and are asked to provide practical examples of how these theories correspond with (media-supported) learning scenarios. Students' reflections on the use of e-learning environments (i.e., 
Moodle, as a learning management system; Mahara, as an ePortfolio space; and Media Wiki, as a free and open-source) helps them develop the ability to use learning theories in the analysis and use of educational technology. Bate's (2015) SECTIONS model has proven very helpful in this context, as it provides students with a framework for considering "the choice and use of media for teaching and learning." Bates' model was first used in the e-education program in 2018, in a course called eEducation12. Before the introduction of the model, students studied learning theories and wrote a short paper on a media-supported learning scenario. Pages were set-up on the course's Media Wiki, with the topics of the students' papers, for their work with the model. The model's criteria for media selection (Bates, 2015) were presented to students in German (Figure 1).

\section{Figure 1}

The SECTIONS Model in e-Education Program (in German), based on A.W. Bates (2015)

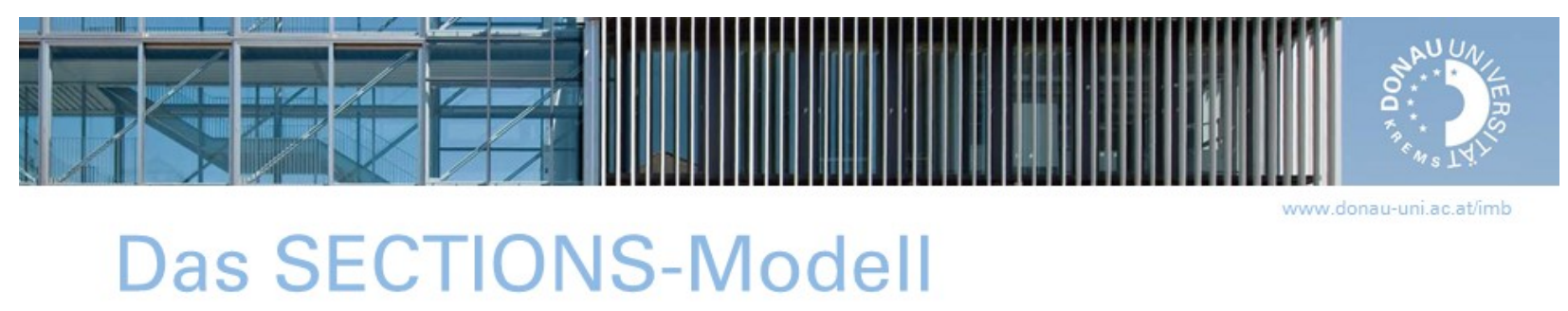

Auswahl von technologischen Werkzeugen/Medien nach dem Modell von Bates (2015)

\begin{tabular}{|c|c|}
\hline Students (Zielgruppe) & für welche Zielgruppe? ICT-Kenntnisse? Endgeräte? ... \\
\hline Ease of Use (BenutzerInnenfreundlichkeit) & Einschulungsbedarf \\
\hline Costs (Kosten) & Aufsetzen, Einrichten, Instandhaltung, Service, ... \\
\hline $\begin{array}{l}\text { Teaching Functions } \\
\text { (PädagogischeEinsatzmöglichkeiten) }\end{array}$ & $\begin{array}{l}\text { welche Fähigkeiten sollen entwickelt werden, passt das Werkzeug } \\
\text { zum Inhalt, zu den Übungen, ... }\end{array}$ \\
\hline Interaction (Interaktivität) & $\begin{array}{l}\text { zwischen Lehrenden \& Lernenden, zwischen Lernenden, wer soll } \\
\text { Inhalte bereitstellen/generieren? }\end{array}$ \\
\hline Organisational issues & $\begin{array}{l}\text { "Maturity" der Institution, an der ich das Werkzeug anwenden } \\
\text { will, bürokratische Erfordernisse, vorgegebene } \\
\text { Lernräume/Hardware/Software }\end{array}$ \\
\hline Networking & $\begin{array}{l}\text { über den Kurs/die Bildungsinstitution hinaus } \\
\text { Vernetzungsmöglichkeiten schaffen/anbieten }\end{array}$ \\
\hline Security and Privacy & Datensicherheit, Privatsphäre beim Lernen... \\
\hline
\end{tabular}

Department für Interaktive Medien und Bildungstechnologien

Donau-Universität Krems. Die Universität für Weiterbildung.

Note. Adapted from eEdu13_bildungstech1ePortfolio, by A. Ghoneim, 2019, Danube University Krems.

Bates' (2015) SECTIONS model for choosing and using media (and/or technology) in education is built around nine criteria. In Chapter 8 of Teaching in a Digital Age, Bates (2015) presents basic information on each criterion and questions for consideration: 
- Students: As students are the main target group for media use in education, one must consider student demographics, student access to the chosen media/technology, and differences in how students learn. Questions for consideration include, "If your students are to be taught at least partly off-campus, to which technologies are they likely to have convenient and regular access at home or work?” (Chapter 8.24).

- Ease of use: The ability of students to use the technology as intuitively as possible must be considered. This criterion also includes issues of support needs and considers questions, such as "How easy is it to maintain the technology?" (Chapter 8.3).

- Cost: Institutional costs for technology development, delivery, maintenance, and overheads (e.g., licensing), which cannot be allocated to a single course, should also be considered. Bates provides a table of cost factors from an instructor's perspective (Chapter 8.4).

- Teaching and media selection: Using Mayer's 12 principles of multimedia design (Mayer 2009), Mayer discusses 12 principles that shape the design and organization of multimedia presentations. These principles are coherence principle, signaling principle, redundancy principle, spatial contiguity principle, temporal contiguity principle, segmenting principle, pre-training principle, modality principle, multimedia principle, personalization principle, voice principle, and image principle. Bates identifies important pedagogical questions for consideration, for example, who are my students? or What content needs to be covered? (Chapter 8.5.4).

- Interaction: Bates divides media interaction characteristics into inherent, designed, and learnergenerated interactivity. These interactions must be considered as well as the interaction of materials, teachers, and learners (and between the learners). Besides, the effective use of teachers' time should be taken into account: "What kinds of interaction will produce a good balance between student comprehension and student skills development, and the amount of time I will be interacting personally or online with students?” (Chapter 8.6).

- Organizational issues: Technologies that are implemented in an institution, as well as existing support for their use, should be considered. When technologies and support are available, teachers can work with professional media designers and consult with them to set appropriate goals for media and technology use (Chapter 8.7).

- Networking: The influence of social media in the application of networking in course design should be considered as well as the potential use of social media as a supplement to standard learning technologies. Student-generated learning materials, cMOOCs, and instructor-led OERs should also be considered in this context. Bates recommends considering the following questions, "How important is it to enable learners to network beyond a course, with others such as subject specialists, professionals in the field, and relevant people in the community? Can the course, or student learning, benefit from such external connections?” (Chapter 8.8). 
- Security and privacy: While in recent years many social media services have moved to online clouds and teaching and learning has become more open and public, Bates emphasizes the importance of considering concerns regarding students' privacy (Chapter 8.9).

Following the introduction of the model criteria, students worked in pairs to complete an assignment, using the model:

1. Interview your peer: Ask them about the tool/medium they presented in their paper. Consider how you would evaluate their tool using the SECTIONS model.

2. Write an entry about the tool in the course Wiki and discuss the learning theories that correspond with the use of the tool.

The instructor suggested that students with similar paper topics form pairs. Each pair was responsible for editing two Wiki pages (about two media). In a follow-up assignment, students were asked to enhance the interlinks of their Wiki pages by adding other pages from the course Wiki. The students found the SECTIONS model criteria very useful not only in completing the assignment but also in their professional work. Furthermore, some of the students' e-portfolios for the course showed that they had read more of Bates' (2015) book to complete their assignments on the use of educational technology.

The following year, work with the SECTIONS model was repeated in the module on educational technology. In the second iteration, Media Wiki was replaced with Moodle Wiki because students wanted to work with the tools (such as editing a document together) that Moodle offers, though the assignment remained the same. Bates' book was included in the recommended literature for the module, and some students had read parts of Teaching in a Digital Age before the presentation on the SECTIONS model and the assignment. One of the students found a diagram of an older version of the SECTIONS model (Bates \& Poole, 2003; Figure 2) and posted it in the class Wiki. The other students did not comment on the diagram, nor did they seem to notice that two of the criteria differed from the model used in the course. According to Bates and Poole (2003), N stands for "novelty" and S stands for "speed"; whereas, according to Bates (2015), N stands for "networking" and S stands for "security and privacy." 


\section{Figure 2}

Bates and Poole's (2003) SECTIONS Model

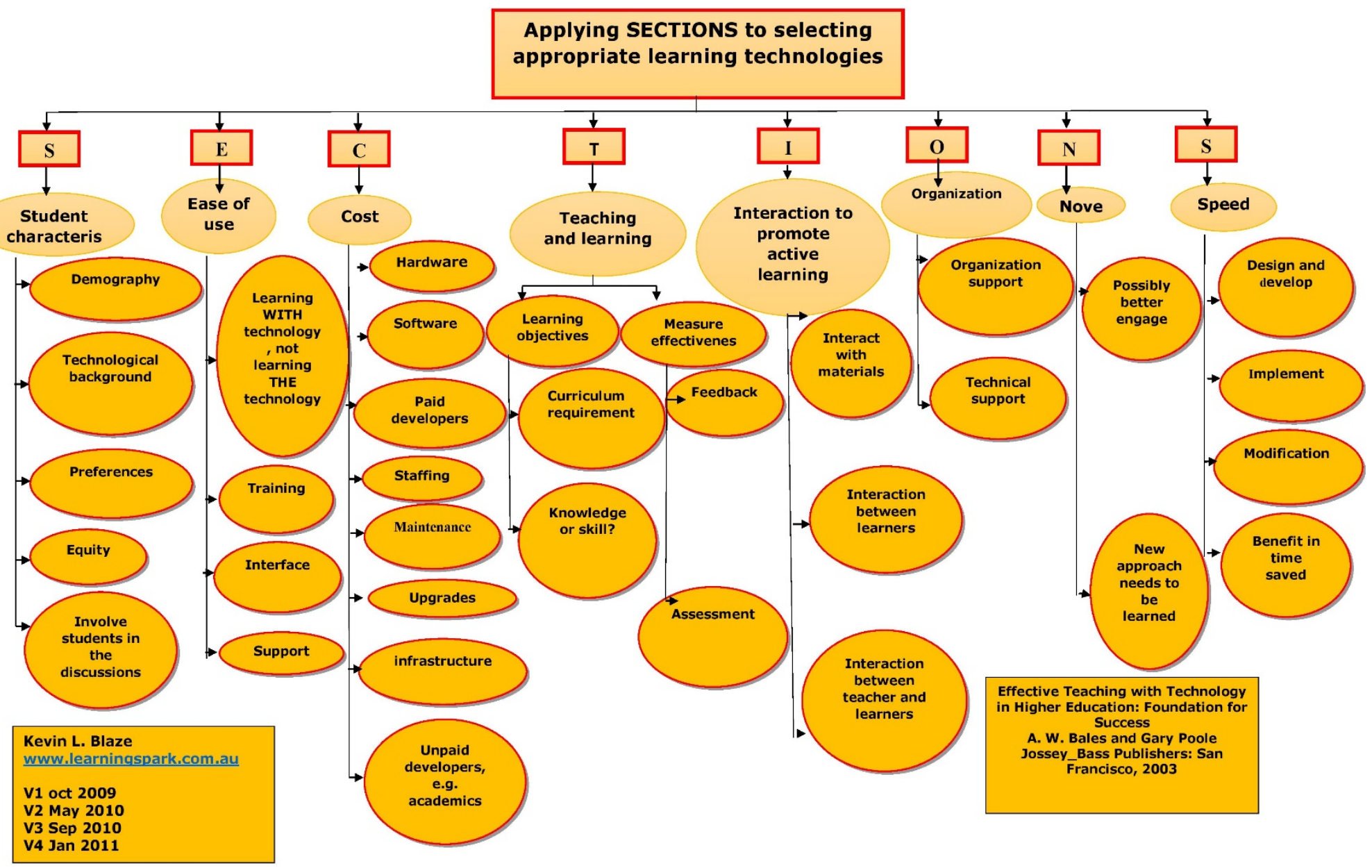

Note. Adapted from Applying SECTIONS to selecting appropriate learning technology [Diagram], by Kevin L. Blazé, 2011, Ringwood North, Australia (http://learningspark.com.au/2017/teaching-withtechnology).

\section{Using Teaching in a Digital Age at Torbat Heydariyeh University of Medical Sciences}

Torbat Heydariyeh University of Medical Sciences is a public university located in Khorasan Razavi province in northeastern Iran. More than 1000 students are enrolled at the university, and currently, the institution grants more than 15 different degrees at the undergraduate, graduate, and doctoral levels. The university comprises three schools that offer diverse academic programs in the medical sciences: the School of Health, the School of Paramedic Sciences, and the School of Nursing and Midwifery. The university administrators are working on establishing a medical school as well. It should be noted that according to the spatial planning document from the Ministry of Health, Medical Sciences universities in Iran are divided into 10 macro-regions. Torbat Heydariyeh University of Medical Sciences, along with other universities in the east of the country, is located in the macro-region 9 (Secretariat of the headquarters for 
transformation in the education. n. d). The Virtual Education Center, one of the best teaching facilities at the university, was established in 2018 and occupies 550 square-meters. The center's faculty members and staff specialize in virtual education planning, health information technology, and educational management. The center has an acoustic room, an audio/video recording studio, an online testing center, and a webinar room, a server farm room, an educational technology lab, as well as the university's Department of New Educational Technology (Figure 3). The history of e-learning activities at this university goes back to 2014 when the learning management system (LMS) was launched to implement blended courses (Virtual Education Center, 2018).

\section{Figure 3}

The Voice and Image Recording Studio

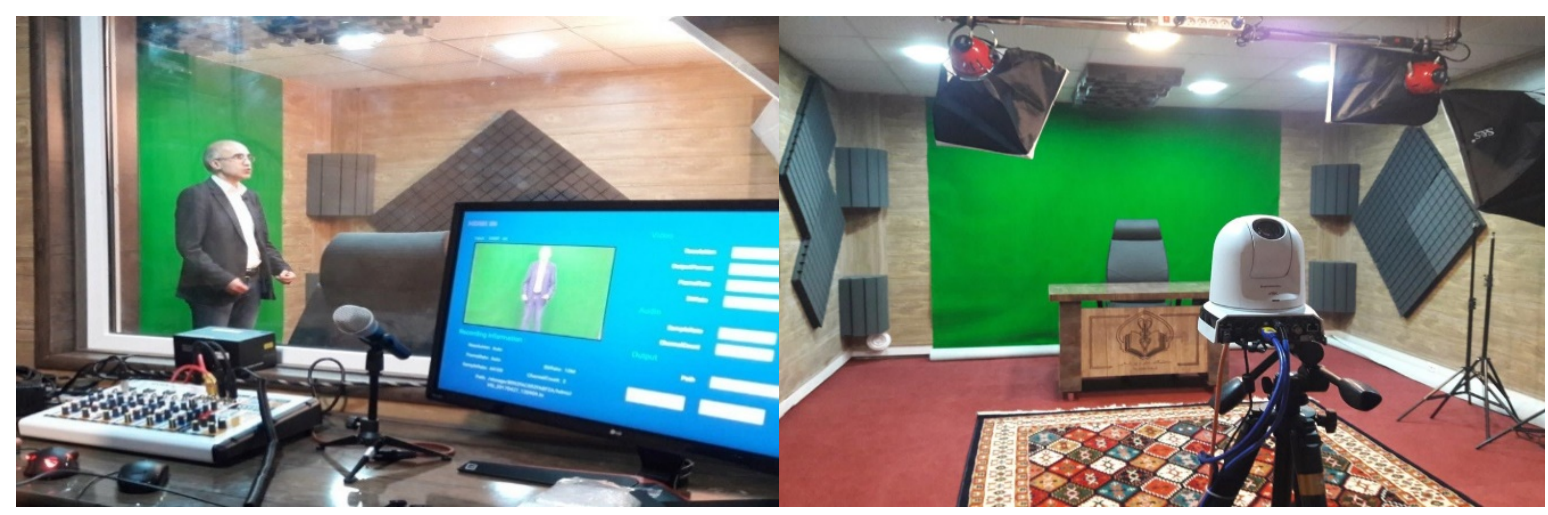

Note. Left panel: Ali Gorji, Visiting Professor and Director of the Epilepsy Research Center, Münster University, Germany; Right panel: The interior of the Voice and Image Recording Studio.

In 2018, Torbat Heydariyeh University of Medical Sciences signed a contract with Iran's Virtual University of Medical Sciences to produce 34 items of electronic content for the national MOOCs (Virtual University of Medical Sciences, 2018). The Virtual University of Medical Sciences was established in 2017, under the direct supervision of the Deputy of Education of the Ministry of Health in Iran, to develop and strengthen virtual education at medical sciences universities. Its main goals are to lead and establish virtual education standards among virtual education centers and colleges and develop programs for virtual medical education in the medical sciences universities. To accomplish these goals, educational policymakers at the Virtual University of Medical Sciences undertook the establishment of a national MOOC platform, ARMAN MOOCs (Figure 4). ARMAN is a Farsi abbreviation for New and Massive National Computerized Education. ARMAN MOOCs are the only national MOOCs in Iran in the field of medical sciences. One of the main tasks of the Virtual University of Medical Sciences was to produce e-content for the national MOOCs, with the help of medical sciences universities across Iran. For this purpose, the Virtual University of Medical Sciences developed a set of principles and technical standards for e-content and issued two calls for its production in 2018 and 2019.

The ARMAN MOOCs are in Farsi, but its platform managers aim to develop the MOOC nationally and internationally. Hundreds of electronic materials are now available in the area of medical sciences and the 
numbers are increasing. Currently, many medical sciences universities throughout Iran are cooperating with this MOOC.

\section{Figure 4}

Home Page of the ARMAN MOOC Website

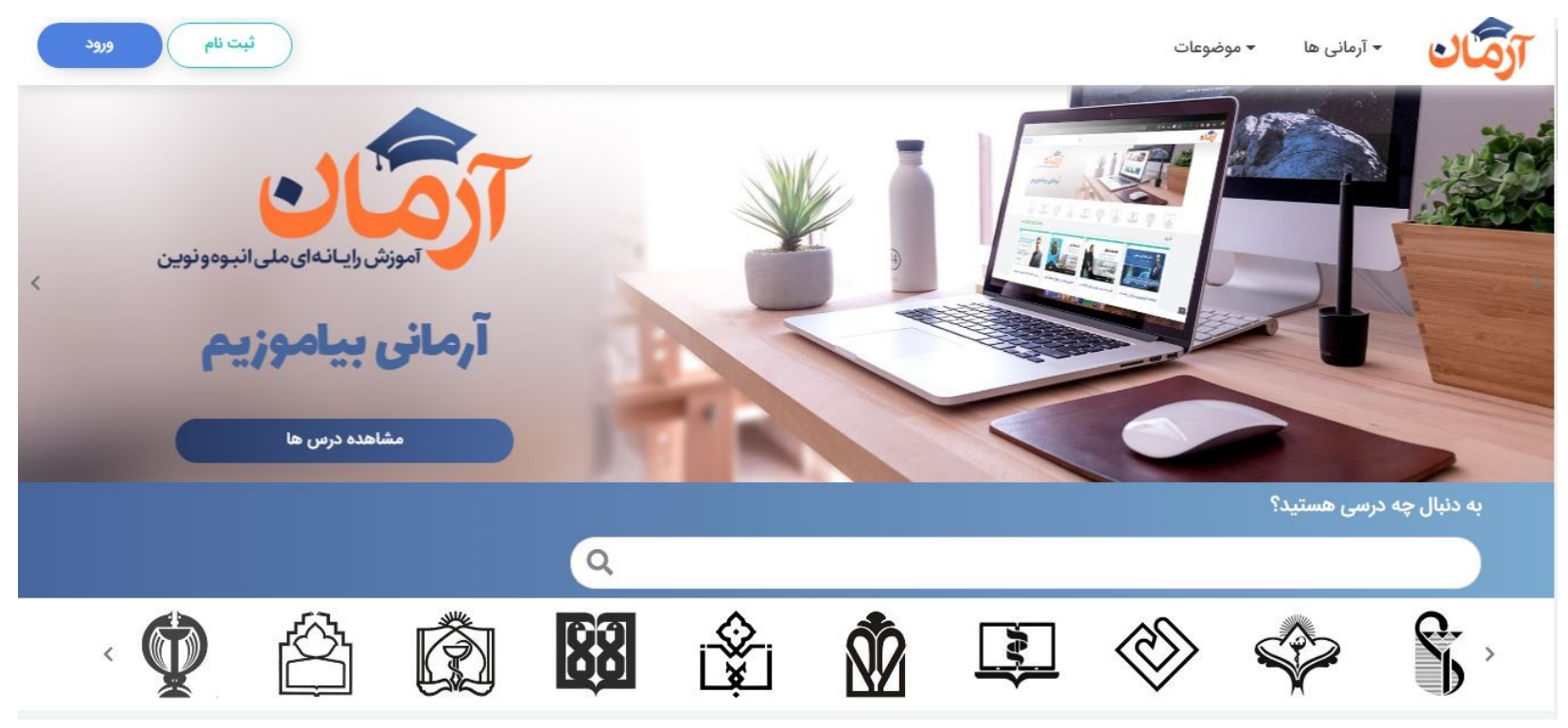

Before setting up the Virtual Education Center in 2018, faculty members of Torbat Heydariyeh University of Medical Sciences mainly used traditional teaching methods and were not familiar with virtual teaching. To implement educational technology at the university, the Virtual Education Center had first developed the technological infrastructure needed to produce electronic content. The Center then designed several workshops to familiarize faculty members with the concepts of modern educational technology. The first and third workshops were held at the beginning of 2019 and were each 6 hours in length. The second workshop was about one hour in length and due to the short time, participants were introduced to the concept of MOOCs in summary after the second workshop individually, in-person and virtually. The first workshop, From Blackboard to MOOC, was held on January 16, 2019, at Mashhad University of Medical Sciences, by invitation of the Director of Medical-Education Development (Keshavarz,2019, January 16). Faculty members from Torbat Heydariyeh University, Mashhad University, and other medical sciences universities in macro-region 9 (e.g., Bojnurd University, Birjand University, Sabzevar University, and Neyshabur University) participated in the workshop. A. W. Bates (2019b) prepared a short video to welcome participants to the workshop and to introduce his book Teaching in a Digital Age. The video was uploaded to YouTube on January 13, 2019 (Figure 5). In this clip, Dr. Tony Bates summarizes the importance of "Teaching in the Digital Age" and explains that this book provides guidance and practical instructions for educational designers and teachers in the digital age, and this book has been translated into various languages around the world. In the end, he thanked Dr. Keshavarz, lecturer of the workshop, and his team for paying attention to this book and translating the book into Persian. 


\section{Figure 5}

\section{Bates' Introduction to From Blackboard to MOOC Workshop}

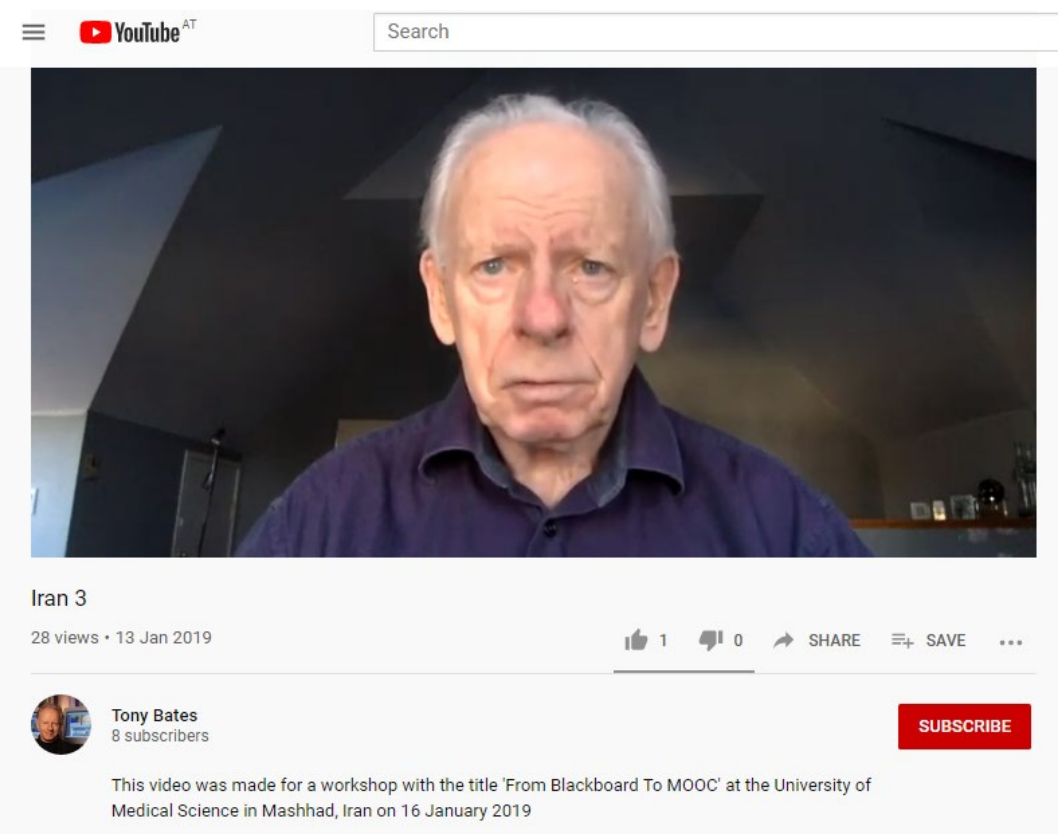

Note. From Introduction to From Blackboard to MOOC [Video], by T. Bates, 2019, YouTube (https://www.youtube.com/watch?v=llTfFy6nKSQ).

Before the workshop, participants completed a multiple-choice questionnaire to assess their knowledge about MOOCs. Results of the questionnaire revealed that the faculty members had very little knowledge in this area. The workshop began with a presentation of the video that Bates (2019b) prepared to establish the international character of the workshop. The workshop instructor then introduced the concept, history, and types of MOOCs based on Chapter 5 of Teaching in a Digital Age (2015) as well as examples and models from the book (Figure 6). For many faculty members, this was their first encounter with MOOCs. The Farsi translation of Teaching in a Digital Age (Bates, 2015, 2016), was also introduced. Participating faculty members reported that they were very satisfied with the workshop. 


\section{Figure 6}

From Blackboard to MOOC Workshop Presentation
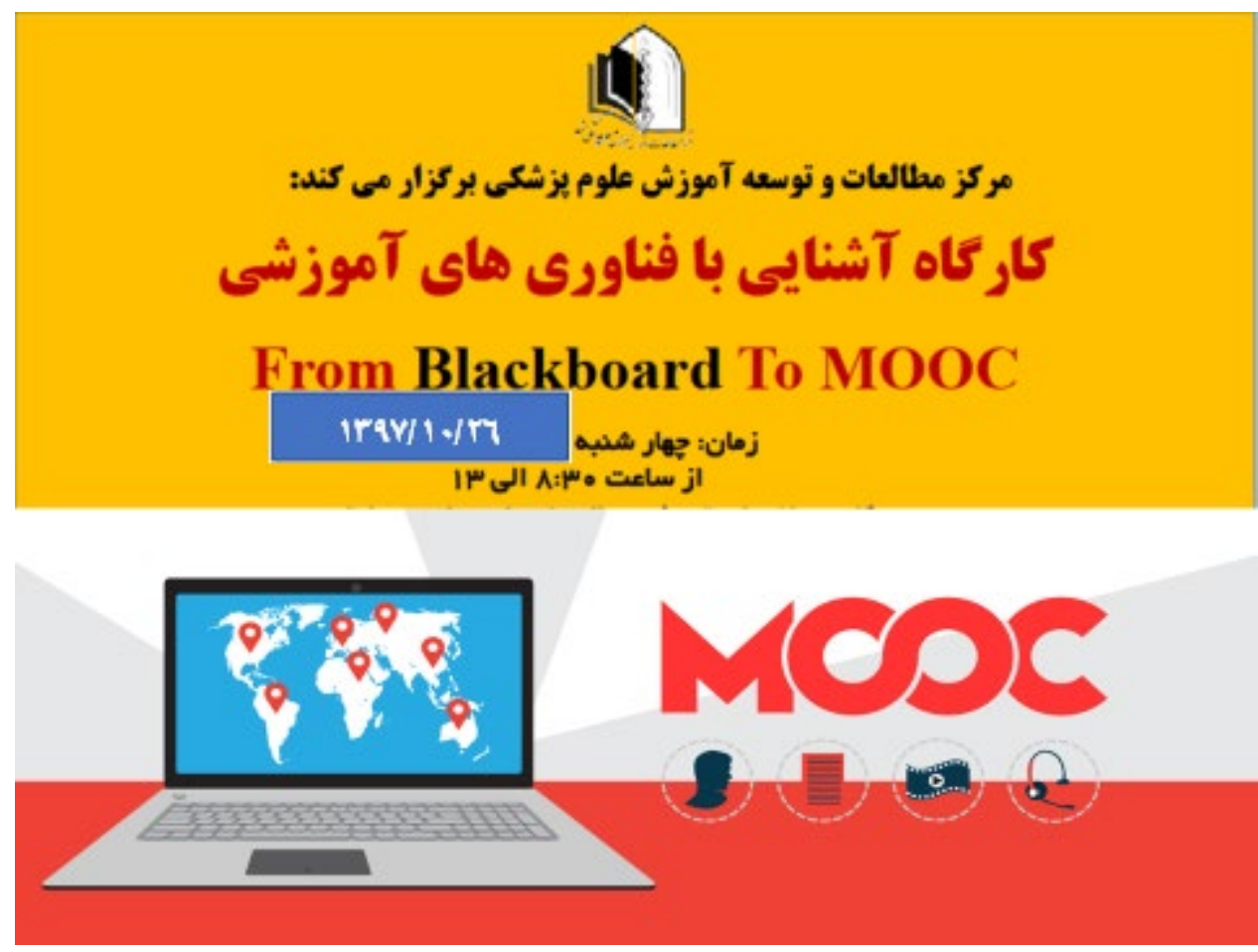

Note. Adapted from From Blackboard to MOOC [Workshop presentation], by M. Keshavarz, (2019, January 16), Mashhad University of Medical Sciences, Iran.

The second workshop, "Introduction to MOOCs," was held at Mashhad University of Medical Science on February 13, 2019. In the fourth part of this workshop, which also covered the concept of MOOCs, using the book Teaching in a Digital Age focused on introducing the MOOCs concept.

It should be noted that in addition to the faculty members of Mashhad University of Medical Sciences, several faculty members of medical sciences universities of the $9^{\text {th }}$ macro-region also participated in this workshop (Figure 7). 


\section{Figure 7}

Introduction on MOOCs Workshop Presentation

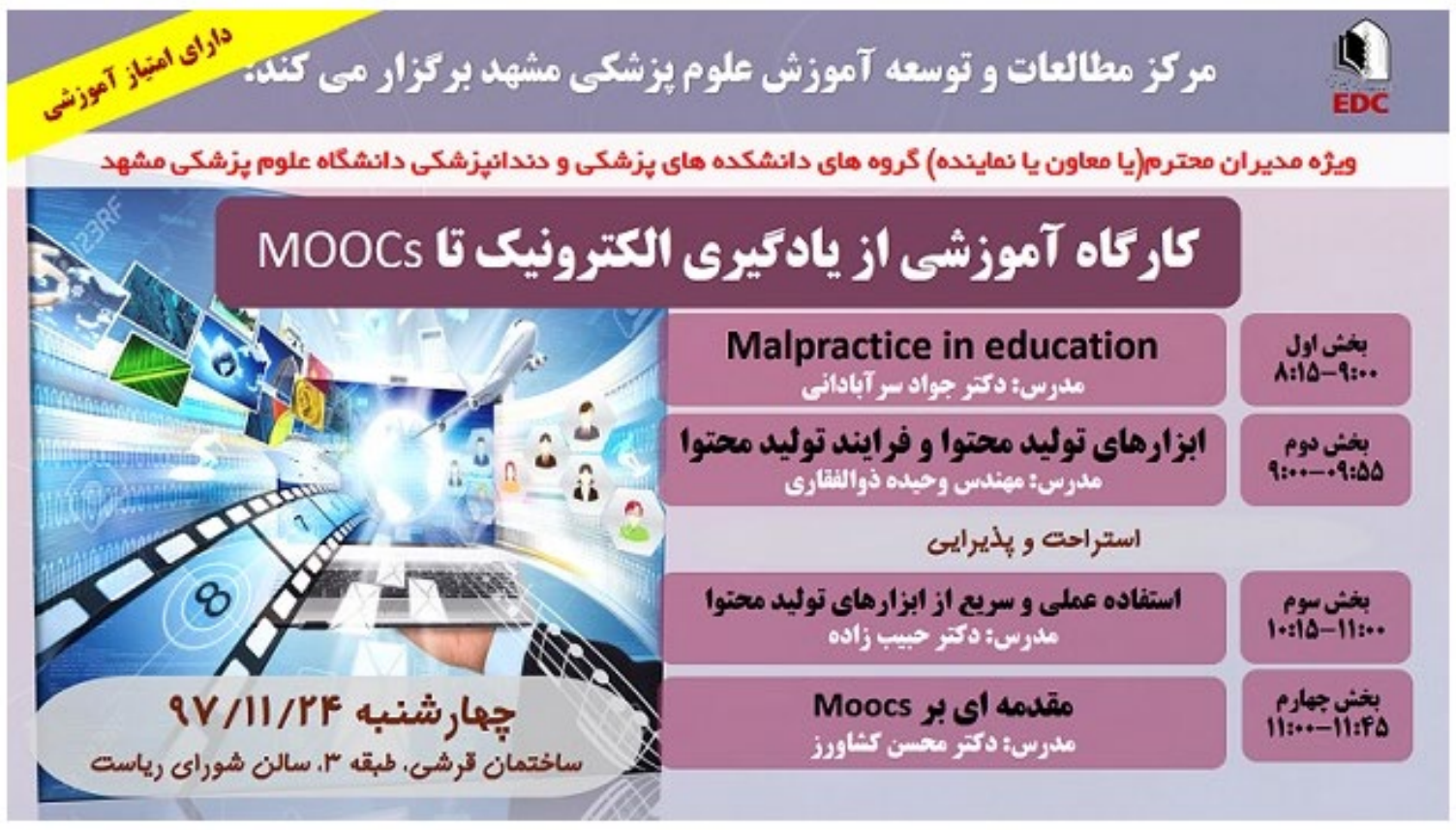

Note. Adapted from Introduction on MOOCs: The fourth part [Workshop presentation], by M. Keshavarz, (2019, February 13), Mashhad University of Medical Sciences, Iran.

Also, one of the main goals in holding this type of workshop outside Torbat Heydariyeh University of Medical Sciences was the possibility of participation from all faculty members of medical sciences universities in macro-region and inter-university cooperation in the education transformation headquarters.

Following the two workshops, faculty members who visited the Virtual Education Center to learn more were offered personal consultations. In these consultations, Center staff explained digital teaching methods and the importance of MOOCs as a teaching tool. The consultations raised interest among faculty members in using virtual teaching methods. After the workshops and consultations, faculty members continued to visit the Virtual Education Center, and they have gradually become interested in producing electronic content and using blended teaching methods in their courses.

Another workshop, Introduction on MOOCs, was held on September 25, 2019, at Bojnurd University of Medical Sciences in North Khorasan Province for faculty members and university administrators. Faculty members of Torbat Heydariyeh of Medical Sciences were also invited to this workshop, with the content for this workshop primarily being drawn from Teaching in Digital Age (Figures 8-9). In addition to providing an introduction to MOOCs, the workshop instructor advised administrators on the development of virtual education infrastructure. As a result of the workshop, Bojnurd University of Medical Sciences administrators are in the process of setting up a professional studio for audio and video recording and 
intend to produce electronic content for the ARMAN MOOC. It should be noted that this workshop was held to provide advice to faculty members from Bojnurd University of Medical Sciences.

\section{Figure 8}

Introduction on MOOCs Workshop Presentation
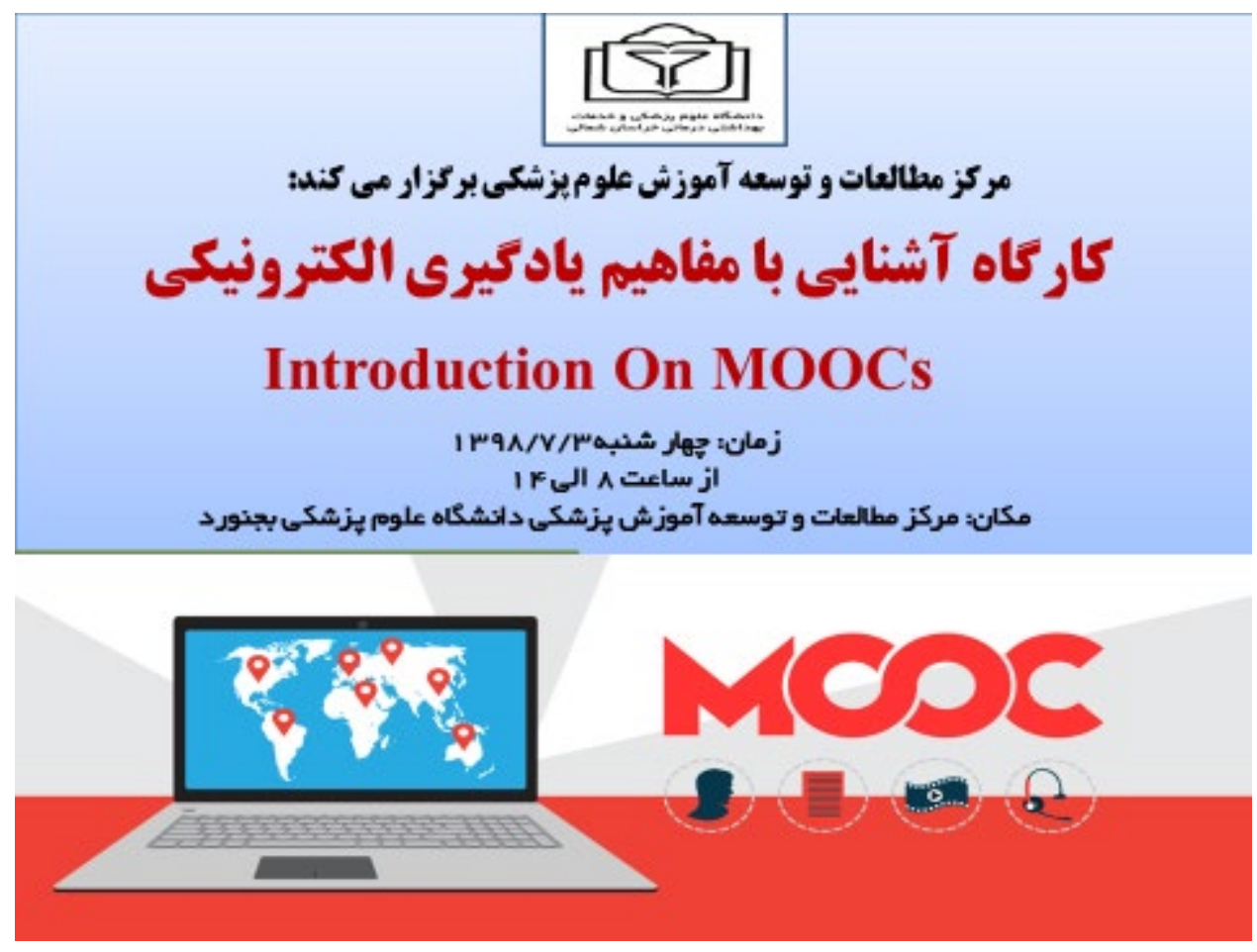

Note. Adapted from Introduction on MOOCs [Workshop presentation].by M. Keshavarz (2019, September 25), Bojnurd University of Medical Sciences, Iran. 


\section{Figure 9}

Introduction on MOOCs Workshop

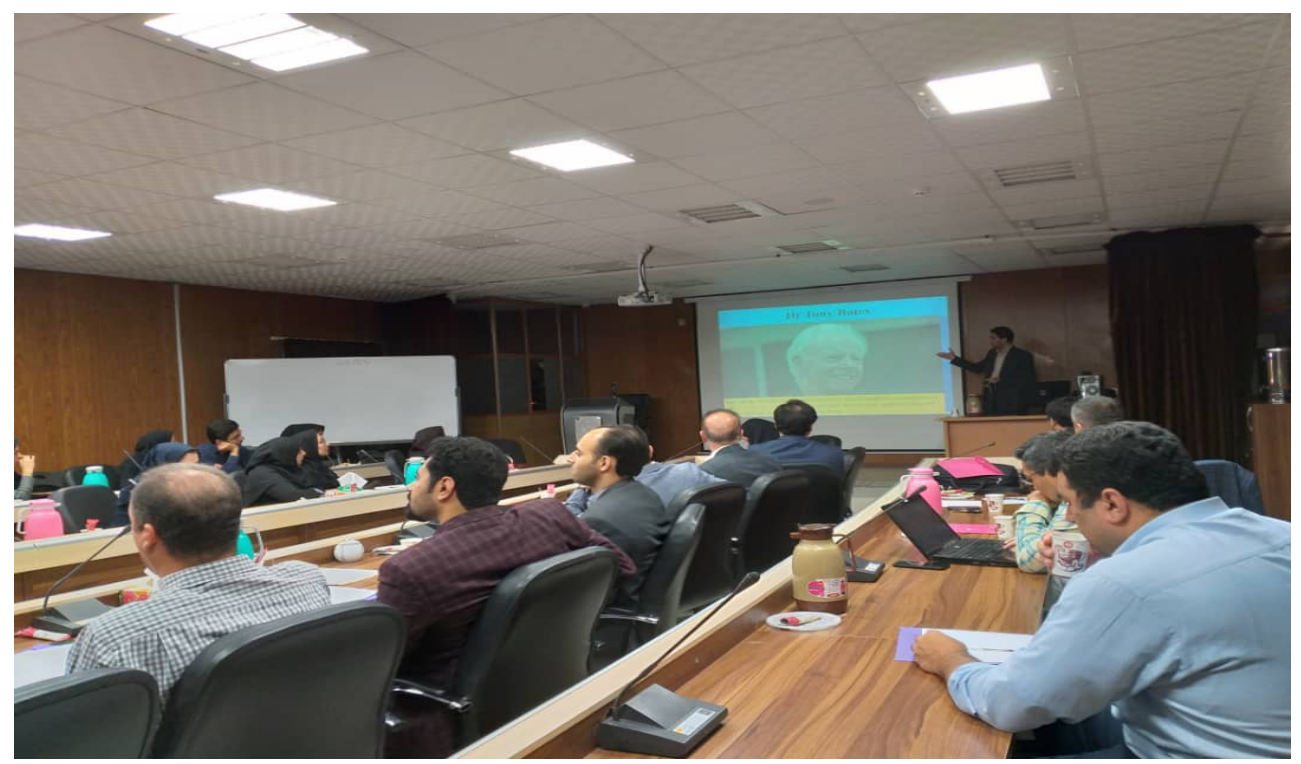

Note. From Introduction on MOOCs [Workshop presentation], by M. Keshavarz (2019, September 25), Bojnurd University of Medical Sciences, Iran.

In October 2019, the Virtual Education Center at Torbat Heydariyeh University of Medical Sciences and faculty from diverse health fields at the university produced 34 items of electronic content for the national ARMAN MOOCs (Virtual University of Medical Sciences, 2018). According to figures 11-12, these econtents are now available to all medical students and students interested in health issues on the ARMAN MOOC Website (2019a). The Virtual Education Center at Torbat Heydariyeh University of Medical Sciences is producing electronic content for the national ARMAN MOOCs and aimed to double the production of electronic content by the end of 2021. As a result, holding workshops on MOOCs had also affected other universities in region 9, with these universities now planning to produce electronic content for ARMAN MOOCs and upgrading e-learning infrastructure. This is a significant expansion of content production for the national ARMAN MOOCs compared to other universities in the field of medical sciences in Iran. It is the objective of the university's second collaboration with the Virtual University of Medical Sciences to produce another 50 electronic materials (2019b).

Teaching in a Digital Age, through workshops and personal consultations have increased the participation of faculty members at the university in the production of electronic content and the use of blended teaching methods in their courses. Faculty members are creating electronic content at an increasing rate. Currently, each of the 76 faculty members at the university collaborates in the production of electronic content and has created items of electronic content in the field of medical sciences. Today, the professors at this university largely present their courses through blended learning and national learning management systems, called NAVID, and the students appear to welcome the flexibility these methods afford. The Virtual University of Medical Sciences is responsible to create and develop a national learning management 
system, NAVID is an abbreviation in Persian means "Special Software for University Learning" (Figure 10). Currently, NAVID and ARMAN are two new educational technologies among the medical sciences universities in Iran, which are used to promote teaching and learning in the online environments and especially in the current context of COVID and university closures. In the end, it must be said that now, Torbat Heydariyeh University of Medical Sciences, with extensive activity in the field of e-learning and in line with the development of virtual education, has become an e-learning and virtual education hub among medical sciences universities in Eastern Iran.

\section{Figure 10}

Home Page of the NAVID Website: National Learning Management System

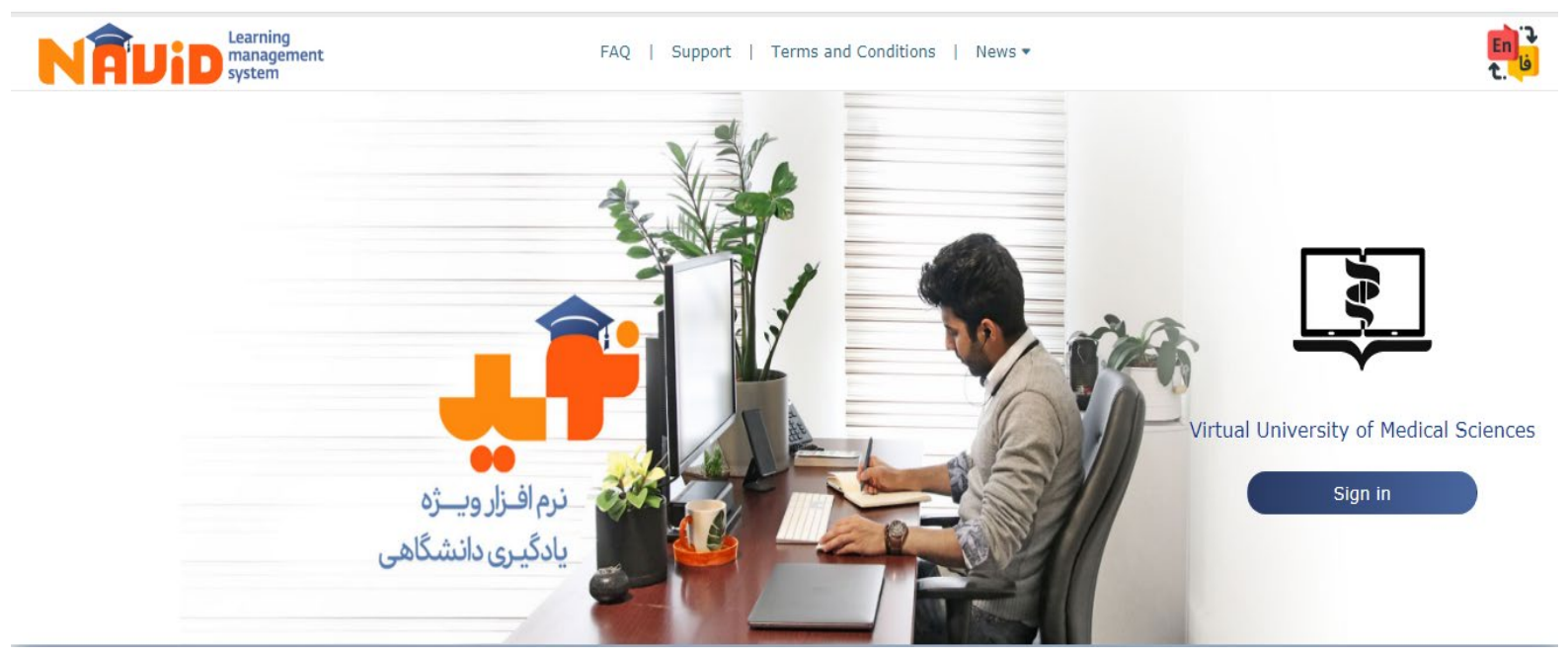

\section{Figure 11}

Sample of Electronic Contents on ARMAN MOOC Website by Torbat Heydariyeh University of Medical Sciences

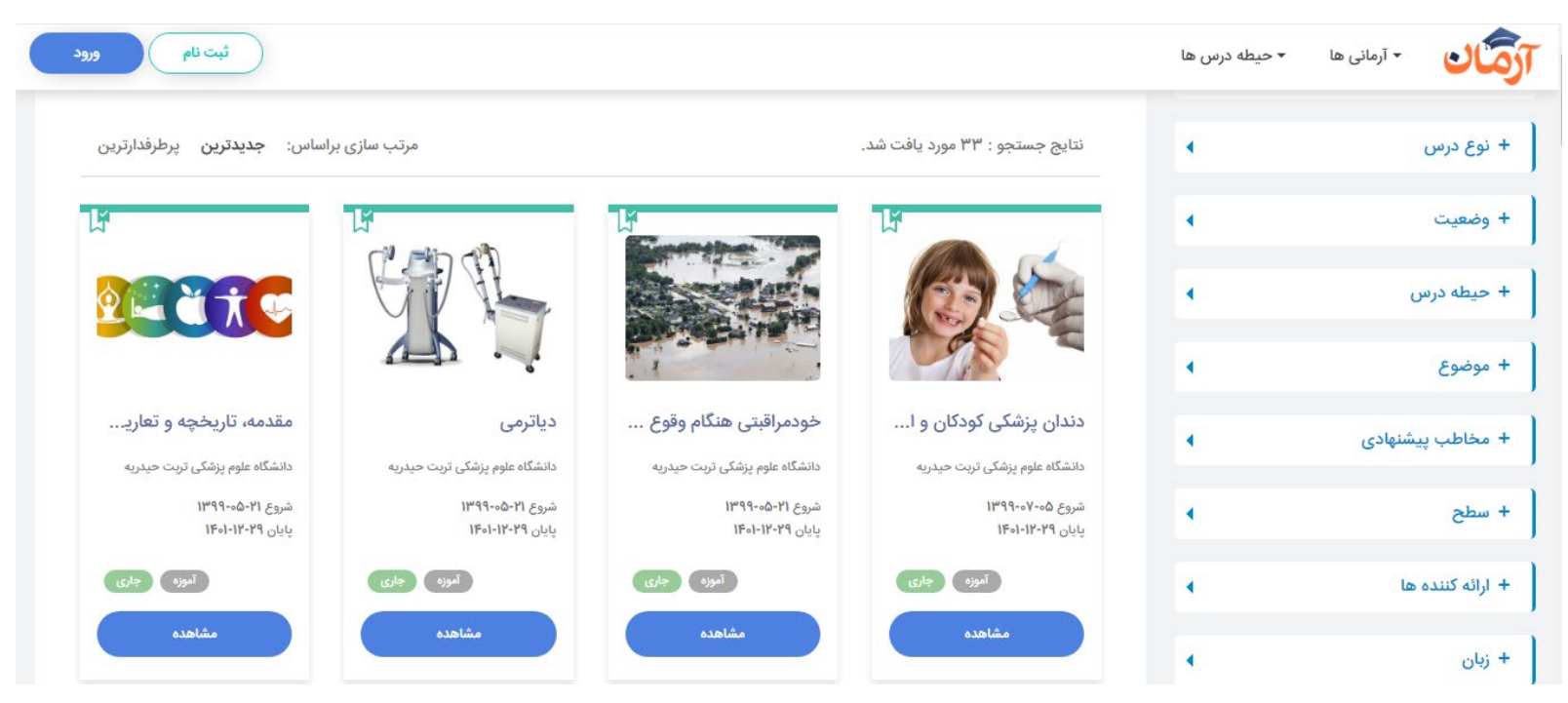




\section{Figure 12}

Sample of Electronic Contents on ARMAN MOOC Website by Torbat Heydariyeh University of Medical Sciences
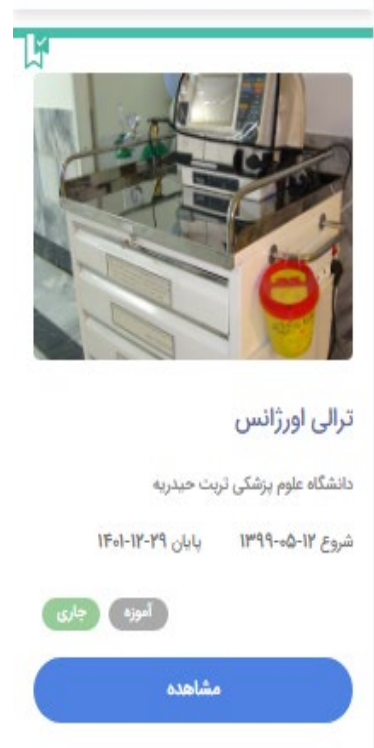
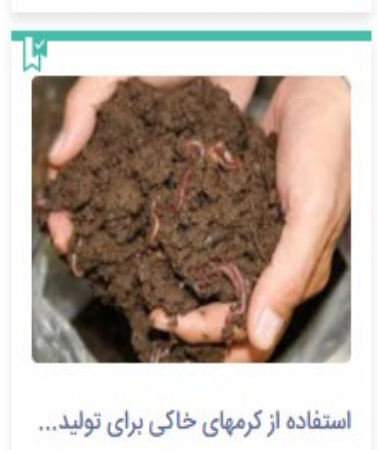

دانشكاه علوم يزشكى تربت حيدريه

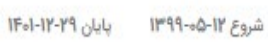

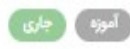

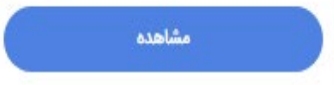

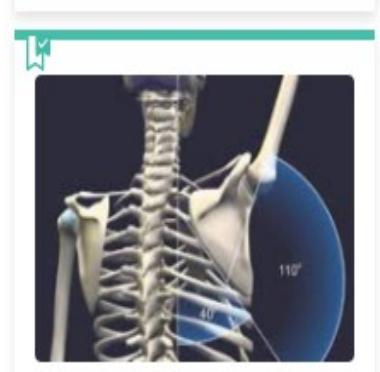

استخوان هاى كمربند شانه ايى

دانشكاه علوم بزشكى تربت حيدربه

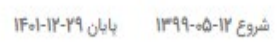

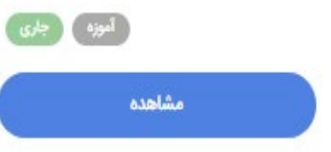

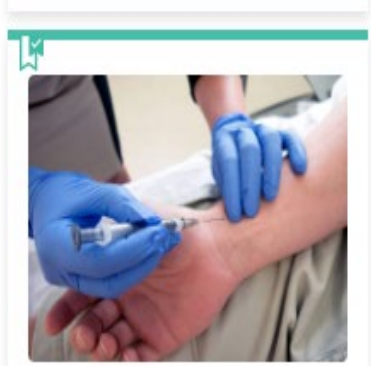

تفسير كازهاى خون شريانى (ABG)

داشكاه علوم بششكى تربت حيلريه

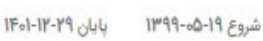

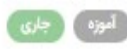

araline

Torbat Heydariyeh University has expanded the use of virtual education among its faculty members by familiarizing them with MOOCs and e-learning methods, using Teaching in a Digital Age (Bates, 2015) in workshops and personal consultations. The use of Bates' seminal book at the university and in macro-region 9 has contributed to:

- the introduction of new educational technology, such as MOOCs, virtual reality, augmented reality, and gamification to faculty members; and the presentation of workshops about e-learning at other large medical sciences universities in the macro-region 9; and planning to hold educational fellowships in the field of e-learning.

- an increase in faculty members' motivation, interest, and flexibility in using new teaching methods, both virtual and hybrid, in their courses, and an increase in student access to faculty content, and creating a dynamic movement in the universities of the macro-region 9 to establish e-learning standards.

- the production of mass electronic content in the field of medical sciences by faculty members, and the generation of income from sales of virtual education products.

- This research is a kind of the scholarship of teaching and learning (SOTL), faculty development efforts to enhance teaching and learning is one of the main topics in SOTL. As such, SOTL surrounds aspects of professional faculty development, such as how teachers can develop their professional teaching expertise, i.e., how to better teach students in the field or enable their 
learning in the digital age. It also encompasses the study and implementation of more modern teaching methods, such as online collaborative learning, blended learning and, hybrid learning.

- the achievement of scientific leadership in the field of virtual education among the medical sciences universities in the northeast of Iran by the National Agency for Strategic Research in Medical Education: NASR (Yazdani \& Hoseini, 2020).

- the attraction of new faculty members with e-learning expertise and the initial approval of the Secretariat of the Council for the Development of Medical Sciences Universities in the Balanced National Document on Health Higher Education in Iran on the Horizon of 2030: macro-region 9, to establish an academic department in e-learning at the university as a Master of Science degree for the first time in the macro-region 9 (Secretariat of the Council for the Development of Medical Sciences Universities, 2020).

- Establishment of a Virtual Education Center under the standards of the Virtual University of Medical Sciences of the Ministry of Health.

- the presentation of teaching courses through virtual education when dealing with epidemics, such as the Coronavirus, and seasonal diseases, and the closure of universities.

- Achieving 15th rank in the development of virtual education among medical sciences universities across the country: $R A D 3$ (Ershadi et al., 2020).

\section{Conclusion}

The use of Teaching in a Digital Age (Bates, 2015) in workshops and personal consultations at an Iranian university and in a blended-learning course at an Austrian university has inspired faculty members and students to broaden and deepen their knowledge about educational technology, the production of content for technology-supported learning via MOOCs, and media-supported teaching and learning. Teaching in a Digital Age is a seminal book in the field of educational technology; and its author, A. W. Bates, is a leading educational theorist in the field. Applying the models presented in his book to academic settings can lead to effective e-teaching and e-learning. For this reason, the authors attempted to implement the book's insights in their academic settings. Both authors achieved positive results in their academic environments. Parts of the first edition of Teaching in a Digital Age have been translated into Farsi and are available on the BCcampus site, while a German translation is not yet available. A Farsi translation of the second edition will be completed by the end of 2021. The authors hope that the second edition will lead to additional translations of the book that serves as an excellent resource for educators to become acquainted with mediasupported teaching and learning. 


\section{Acknowledgements}

Dr. Mohsen Keshavarz would like to express thanks to his committee, Dr. Tony Bates in Canada and Dr. Andrea Ghoneim at Danube University Krems in Austria, for their continued support and encouragement. He offers sincere appreciation for the International learning opportunities provided by his committee. The completion of this project could not have been accomplished without the support of colleagues in macroregion 9, specifically, Dr. Javad Sarabadani at Mashhad University of Medical Sciences and Mahboubeh Tabatabaeichehr Chehr at Bojnurd University of Medical Sciences. 


\section{References}

Aldahmani, S., Al-shami, S. A., Adil, H., \& Sidek, S. (2020). A Review paper on MOOCs development stages, types, and opportunities, and challenges. Systematic Reviews in Pharmacy, 11(12), 172179.

Anderson, T. (2008). The theory and practice of online learning: Athabasca University Press.

Bates, A. W. (2015). Teaching in a digital age: Guidelines for teaching and learning (1st ed.). Tony Bates Associates Ltd. https://opentextbc.ca/teachinginadigitalage/

Bates, A. W. (2019a). Teaching in a digital age: Guidelines for teaching and learning (2nd ed.). Tony Bates Associates Ltd. https://pressbooks.bccampus.ca/teachinginadigitalagev2/

Bates, A. W. (2019b, January 13). Introduction to From Blackboard to MOOC [Video]. https://www.youtube.com/watch?v=llTfFy6nKSQ\&t=9s

Bates, A. W., \& Poole, G. (2003). Effective teaching with technology in higher education: Foundations for success. Jossey-Bass Publishers.

Baumgartner, P. (2004, September 29-October 1). The Zen art of teaching: Communication and interactions in e-education [Paper presentation]. International Workshop ICL2004, Villach, Austria. Kassel University Press. https://portfolio.peter-baumgartner.net/publication/2004-01o1 baumgartner zen_2004/

Blazé, K. L. (2011). Applying SECTIONS to selecting appropriate learning technology [Diagram], Ringwood North, Australia. http://learningspark.com.au/2017/teaching-with-technology

Duzenl, H. (2018). Teaching in a digital age: Guidelines for designing teaching and learning for a digital age. Turkish Online Journal of Distance Education, 19(2), 218-219. https://dergipark.org.tr/en/download/article-file/458693

Ershad, S.R., Bahaaldini, K., Jahani, Y., Khazaneha, M., Halavati, I., Dashti, M., Dehghani, MR., Sharififar, F., Shoghi, A.F., Fasihi, M., \& Yazdani, S.H. (2020). Educational ranking of the Iranian universities of medical sciences 2019- 2020: (Rad 3). Farhang Publisher.

Ghoneim, A. (2019). eEdu13_bildungstech2 [PowerPoint slides]. Department of Continuing Education Research and Educational Technology, Danube University Krems. https://imbmahara.donauuni.ac.at/view/view.php?id=21

Himpsl, K. (2010). E-Portfolios in berufsbegleitenden Studiengängen zu Neuen Medien [E-portfolios in part-time courses on new media]. MedienPädagogik: Zeitschrift für Theorie Und Praxis Der Medienbildung, 18, 1-25. https://doi.org/10.21240/mpaed/18/2010.05.02.X 
Keshavarz, M. (2019, January 16). From blackboard to MOOC [Workshop]. Department of MedicalEducation Development. Mashhad University of Medical Sciences, Iran. http://edc.mums.ac.ir/kargah/484-workshop5

Keshavarz, M. (2019, February 13). Introduction on MOOCs [Workshop]. The fourth part, Department of Medical-Education Development. Mashhad University of Medical Sciences, Iran. http://edc.mums.ac.ir/kargah/487-elearningworkshop

Keshavarz, M. (2019, September 25). Introduction on MOOCs [Workshop]. Department of MedicalEducation Development. Bojnurd University of Medical Sciences, Iran. http://nkums.ac.ir

Kocdar, S. (2017). Designing teaching and learning for a digital age. The International Review of Research in Open and Distributed Learning, 18(3). https://doi.org/10.19173/irrodl.v18i3.3107

Mayer, R. E. (2009). Multimedia learning (2nd ed.). Cambridge University Press. https://doi.org/10.1017/CBO9780511811678

Mulyono, H. (2018). Teaching in a digital age. Teaching English with Technology, 17(4), 93-96. https://www.ceeol.com/search/article-detail?id=579135

Multimedia Educational Resource for Learning and Online Teaching (MERLOT). (2019). Teaching in a digital age. MERLOT Material. https://www.merlot.org/merlot/viewMaterial.htm?id=1165883

Secretariat of the Headquarters for Transformation in Education. (n.d). Universities of the macro-region 9. Mashhad University of Medical Sciences, Iran. https://ielpc.mums.ac.ir/

Secretariat of the Council for the Development of Medical Sciences Universities. (2020, December 13). Balanced national document on health higher education in Iran on the horizon of 2030. Unpublished document, Latest news and announcements, Ministry of Health and Medical Education, Iran. https://oee.behdasht.gov.ir/

Teacher Education. (2018). Teaching in a digital age: Guidelines for designing teaching and learning for a digital age [Peer review]. MERLOT. https://www.merlot.org/merlot/viewCompositeReview.htm?id=1356177

Virtual Education Center. (2018, August 30). Launching the first professional and standard studio of image and sound in the east of the country, Torbat Heydariyeh University of Medical Sciences, Iran. http://vec.thums.ac.ir/

Virtual University of Medical Sciences. (2018). The first meeting of the Scientific Committee of the ARMAN Council. Deputy of Infrastructure. http://vums.ac.ir/?p=15020

Virtual University of Medical Sciences. (2019a). New and massive national computerized education $(A R M A N)$. http://arman.vums.ac.ir/search/index?selectedProvider=62 
Virtual University of Medical Sciences. (2019b). The national MOOCs Scientific Committee (ARMAN). Deputy of Infrastructure. http://vums.ac.ir/?p=17934

Yazdani, S.H., \& Hoseini, A.M (2020). Scientific supremacy in Torbat Heydariyeh University of Medical Sciences and Health Services: From an unattainable dream to an achievable ideal. National Agency for Strategic Research in Medical Education (NASR). https://nasrme.ac.ir/macro-region/

\section{Athabasca} University

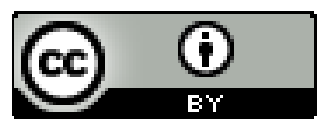

